\title{
Influence of extracellular polymeric substances on deposition and redeposition of Pseudomonas aeruginosa to surfaces
}

\author{
Cristina Gómez-Suárez, ${ }^{1}$ Jos Pasma, ${ }^{1}$ Arnout J. van der Borden, ${ }^{1}$ \\ Jost Wingender, ${ }^{2}$ Hans-Curt Flemming, ${ }^{2}$ Henk J. Busscher ${ }^{1}$ \\ and Henny C. van der $\mathrm{Mei}^{1}$
}

1 Department of Biomedical Engineering, University of Groningen, Antonius Deusinglaan 1, $9713 \mathrm{AV}$, Groningen,

The Netherlands

2 Division of Aquatical Microbiology, Faculty of Chemistry, Gerhard Mercator-University of Duisburg, Lotharstrasse 1, 47057 Duisburg, Germany
Author for correspondence: Henny C. van der Mei. Tel: +3150 3633140. Fax: +31503633159. e-mail: h.c.van.der.mei@med.rug.nl

In this study, the role of extracellular polymeric substances (EPS) in the initial adhesion of EPS-producing Pseudomonas aeruginosa SG81 and SG81R1, a nonEPS-producing strain, to substrata with different hydrophobicity was investigated. The release of EPS by SG81 was concurrent with a decrease in surface tension of a bacterial suspension from 70 to $45 \mathrm{~mJ} \mathrm{~m}^{-2}$ that was absent for SG81R1. Both strains adhered faster and in higher numbers to a hydrophilic than to a hydrophobic substratum, but the initial deposition rates and numbers of adhering bacteria in a stationary-end point were highest for the non-EPS-producing strain SG81R1, regardless of substratum hydrophobicity. Both strains adhered less to substrata pre-coated with isolated EPS of strain SG81. Furthermore, it was investigated whether bacteria, detached by passing air-bubbles, had left behind 'footprints' with an influence on adhesion of newly redepositing bacteria. Redeposition on glass was highest for non-EPSproducing SG81R1 and decreased linearly with the number of times these cycles of detachment and deposition were repeated to become similar to the redeposition of SG81 after six cycles. This indicates that $P$. aeruginosa SG81 leaves the substratum surface nearly completely covered with EPS after detachment, while SG81R1 releases only minor amounts of surface active EPS, completely covering the substratum after repeated cycles of detachment and adhesion. Atomic force microscopy showed a thick and irregular EPS layer (up to $32 \mathrm{~nm}$ ) after the first detachment cycle of EPS-producing strain SG81, whereas the putatively non-EPS-producing strain SG81R1 left a $9 \mathrm{~nm}$ thin layer after one cycle. X-ray photoelectron spectroscopy indicated that the bacterial footprints consisted of uronic acids, the prevalence of which increased with the number of detachment and deposition cycles.

Keywords: proteins, polysaccharides, bacterial adhesion, footprints, atomic force microscopy

\section{INTRODUCTION}

Micro-organisms readily deposit and adhere to all surfaces immersed in an aqueous environment as the onset of a multi-step process, leading to the formation of a complex, adhering microbial community termed

Abbreviations: ADSA-P, axisymmetric drop shape analysis by profile; AFM, atomic force microscopy; DDS, dimethyldichlorosilane; EPS, extracellular polymeric substance(s); XPS, X-ray photoelectron spectroscopy. 'biofilm'. Although the function and appearance of biofilms in various environments may be different, all biofilms form from the same basic sequence of events (Escher \& Characklis, 1990), including (i) the formation of a conditioning film of adsorbed macromolecular components; (ii) transport of micro-organisms towards the substratum surface; (iii) initial, mainly reversible, adhesion of linking film organisms to the substratum surface (Busscher et al., 1995) or alternatively, planktonic micro-organisms may co-adhere to already adhering micro-organisms (Bos et al., 1995); (iv) microbial 
anchoring yielding irreversible adhesion through the production of extracellular polymeric substances (EPS) (Sutherland, 1977; Neu \& Marshall, 1990); (v) growth as the main contributing factor to the accumulation of micro-organisms in a biofilm.

More than $90 \%$ of the EPS volume consists of water (Schmitt \& Flemming, 1999; Sutherland, 1997), located in pores and with a minor portion bound to the EPS molecules (Schmitt et al., 1997; Christensen \& Characklis, 1990). EPS has long been considered to consist only of polysaccharides, but recently considerable amounts of proteins, as well as humic substances, nucleic acids and lipids (Cooksey, 1992; Nielsen et al., 1997; Flemming \& Wingender, 2001) have been identified as EPS constituents. However, differences in chemical composition as well as in function of the different kinds of EPS have been reported (Omar et al., 1983; Beech et al., 1999).

A role of EPS in initial adhesion of Pseudomonas to surfaces has not yet been established. However, it has been found that attachment to an inert substratum stimulates bacterial EPS synthesis (Vandevivere \& Kirchman, 1993; Allison \& Sutherland, 1987). EPS components, like polysaccharides (Fletcher \& Floodgate, 1973; Costerton et al., 1985; Azeredo et al., 1999; Azeredo \& Oliveira, 2000) and proteins (Danielsson et al., 1977; Dûfrene et al., 1996b), enhance bacterial adhesion, while lipopolysaccharides (Williams \& Fletcher, 1996), uronic acids (Pringle et al., 1983) and biosurfactants (Velraeds et al., 1998a; Van Hoogmoed et al., 2000; Heinemann et al., 2000) discourage adhesion.

In most natural environments, cyclic detachment and redeposition of organisms occurs more readily than a single round of deposition and adhesion. Passing airliquid interfaces have been demonstrated to yield extremely efficient detachment forces, as in the oral cavity during eating, speaking, drinking and swallowing (Busscher et al., 1992), on the eye and on contact lenses caused by blinking (Landa et al., 1998), on rocks and ship hulls in marine environments (Cooksey \& Wigglesworth-Cooksey, 1995) and in biodeterioration of monumental buildings by falling rain drops (Urzi et al., 1991). Detached organisms may leave 'footprints' (Neu \& Marshall, 1991) behind, that either consist of cell surface fragments left behind (Neu, 1992), excreted biosurfactants (Velraeds et al., 1998b) or EPS. These footprints form a new surface in the redeposition of a new generation of depositing organisms.

The aim of the present study is to investigate the role of EPS in the initial adhesion of Pseudomonas aeruginosa to substratum surfaces with different hydrophobicities. To this end, the deposition and redeposition after detachment by the passage of an air-liquid interface of an EPS-producing and a putatively EPS-non-producing strain of $P$. aeruginosa was studied in a parallel plate flow chamber.

\section{METHODS}

Bacterial strains and culture conditions. An EPS-producing strain and an isogenic non-mucoid strain of Pseudomonas aeruginosa (SG81 and SG81R1, respectively) were used in this study. Both strains were grown aerobically at $37^{\circ} \mathrm{C}$ in Nutrient Broth (NB; Oxoid). For each experiment, strains were inoculated from NB agar in batch culture for $24 \mathrm{~h}$. This culture was used to inoculate a second culture, which was grown for $16 \mathrm{~h}$ prior to harvesting bacteria by centrifugation $(5 \mathrm{~min}$ at $10000 \mathrm{~g})$. Bacteria were washed twice with Millipore-Q water and suspended in PBS, $\mathrm{pH} 7 \cdot 0\left(\mathrm{~g} \mathrm{l}^{-1}: \mathrm{KH}_{2} \mathrm{PO}_{4}\right.$, $\left.0 \cdot 68 ; \mathrm{K}_{2} \mathrm{HPO}_{4}, 0 \cdot 86 ; \mathrm{NaCl}, 8 \cdot 76\right)$ supplemented with $5 \%(\mathrm{v} / \mathrm{v})$ NB $\left(1.25 \mathrm{~g} \mathrm{l}^{-1}\right)$ medium at concentrations of $3 \times 10^{8} \mathrm{ml}^{-1}$ or $1 \times 10^{9} \mathrm{ml}^{-1}$ for deposition and redeposition experiments, respectively. $\mathrm{NB}$ medium $(5 \%, \mathrm{v} / \mathrm{v})$ was added to enhance metabolic activity of the organisms without stimulating growth (Habash et al., 1997).

EPS production and isolation. Strains were examined for EPS production using axisymmetric drop shape analysis by profile (ADSA-P; Cheng et al., 1990) through effects of EPS production on the surface tensions of bacterial suspensions. Droplets $(0 \cdot 1 \mathrm{ml})$ containing $1 \times 10^{9}$ cells of both strains $\mathrm{ml}^{-1}$, suspended in PBS ( $\mathrm{pH} 7 \cdot 0$ ), were placed on a clean piece of fluoroethylenepropylene and the circumference of the suspension droplet was monitored during $2 \mathrm{~h}$ in an enclosed chamber at room temperature. Droplet circumferences were recorded twice with a minimal time interval $(<0.5 \mathrm{~s})$ between measurements and fitted to the Laplace equation of capillarity, yielding the surface tension of the bacterial suspensions. EPS production was inferred from a decrease in surface tension of the bacterial suspension.

EPS-producing $P$. aeruginosa SG81 cells from a $250 \mathrm{ml}$ culture (containing approximately $2.5 \times 10^{11}$ cells) were washed three times with $60 \mathrm{ml}$ Millipore-Q water and the supernatants containing the EPS were collected. The supernatants were centrifuged again ( $5 \mathrm{~min}, 10000 \mathrm{~g}$ ), decanted and the EPScontaining supernatant was dialysed for $24 \mathrm{~h}$ against Millipore-Q water, using a cellulose membrane with a $14 \mathrm{kDa}$ cutoff (Spectrum). EPS $(150 \mathrm{ml})$ isolated in this manner was mixed with $150 \mathrm{ml}$ PBS for substratum coating in deposition assays.

Physico-chemical characterization of bacterial cell surfaces. Water contact angles $\left(\theta_{\mathrm{w}}\right)$ on lawns of both $P$. aeruginosa strains were determined using the sessile drop technique (Van Oss \& Gillman, 1972; Busscher et al., 1984). Briefly, bacterial cells were layered from Millipore-Q water onto $0 \cdot 45 \mu \mathrm{m}$ pore filters (Millipore) using negative pressure. The filters were left to air dry in ambient air until so-called 'plateau contact angles' could be measured.

Electrophoretic mobilities of $P$. aeruginosa strains were measured in PBS supplemented with $5 \%$ NB medium with a Lazer Zee Meter 501 (PenKem), which uses scattering of incident laser light to enable detection of bacteria at relatively low magnifications. Aliquots of the bacterial suspensions were diluted to a density of approximately $1 \times 10^{8}$ cells ml $^{-1}$ in PBS $(\mathrm{pH} 7 \cdot 0)$ prior to the measurements. The voltage difference across the electrophoresis chamber was set to $150 \mathrm{~V}$ and the electrophoretic mobilities measured were converted to apparent zeta potentials $(\xi)$ through the use of the Von Smoluchowski equation (Hiemenz, 1977).

X-ray photoelectron spectroscopy (XPS) was applied to obtain the overall chemical composition of the microbial cells. After culturing and washing, the bacterial pellets were transferred to stainless steel troughs and frozen in liquid nitrogen. The 
samples were subsequently freeze-dried and the resulting bacterial powder was pressed in small stainless steel cups and inserted into the XPS chamber (S-Probe; Surface Science Instruments). X-rays $(10 \mathrm{kV}, 22 \mathrm{~mA})$ at a spot size of $250 \times 1000 \mu \mathrm{m}$ were produced using an aluminium anode. A scan of the overall spectrum in the binding energy range of $1-1200 \mathrm{eV}$ at low resolution (pass energy $150 \mathrm{~V}$ ) was recorded, followed by scans over a $20 \mathrm{eV}$ binding energy range at high resolution (pass energy $50 \mathrm{eV}$ ) for $\mathrm{C}_{1 \mathrm{~s}}$ (carbon), $\mathrm{O}_{1 \mathrm{~s}}$ (oxygen), $\mathrm{N}_{1 \mathrm{~s}}$ (nitrogen) and $\mathrm{P}_{2 \mathrm{p}}$ (phosphorus). The area under a peak, after linear background subtraction, was used to calculate peak intensities, yielding elemental surface concentration ratios for nitrogen, oxygen and phosphorus to carbon, after correction with sensitivity factors provided by the manufacturer. Bacterial cell surface characterizations were carried out in triplicate on three different bacterial cultures.

Substratum surfaces. Glass microscope slides $(76 \times 25 \times$ $1.5 \mathrm{~mm}$ ) were used as substratum surfaces. Glass surfaces were cleaned with $2 \%(\mathrm{w} / \mathrm{v})$ RBS 35 detergent (Omnilabo International) and alternately rinsed in water, methanol, water again and finally demineralized water. Cleaned glass plates were used as a negatively charged, hydrophilic substratum surface, while hydrophobic, negatively charged surfaces were prepared from cleaned glass by first drying in an oven at $80^{\circ} \mathrm{C}$, followed by silanization in $0.05 \%(\mathrm{w} / \mathrm{v})$ dimethyldichlorosilane (DDS) in trichloroethylene. After silanization for $15 \mathrm{~min}$, the surfaces were rinsed with trichloroethylene, methanol and Millipore-Q water.

Physico-chemical characterization of substratum surfaces. Water contact angles $\left(\theta_{\mathrm{w}}\right)$ of glass and DDS-coated glass, as well as of EPS-coated glass were measured by the sessile drop technique, as described above. Zeta potentials $(\xi)$ of bare glass and DDS-coated glass surfaces in PBS $(\mathrm{pH} 7 \cdot 0)$ were measured by streaming potentials in a parallel plate flow chamber (Van Wagenen \& Andrade, 1980).

In redeposition experiments, the chemical composition of the substrata after air-bubble-induced detachment of adhering bacteria was determined by XPS after the first and second deposition cycle to detect potential footprints. However, since both glass surfaces and EPS are rich in oxygen, complicating the interpretation of XPS data, redeposition experiments were also carried out on gold-coated glass slides to uniquely identify potential EPS material left behind after bacterial detachment. In addition, potential footprints on glass were sought by atomic force microscopy (AFM). AFM images and forcedistance measurements were taken under water at room temperature using an optical lever microscope (Nanoscope IIIa Dimersion 3100; Digital Instruments). Contact mode topographic images were recorded in both height and deflection modes. Height images provided quantitative topographic information from which the mean roughness $\left(R_{\mathrm{a}}\right)$ of the surfaces was calculated, while deflection images revealed finer surface details. The imaging force was kept below $1 \mathrm{nN}$ and the scan rate was in the range of $2-4 \mathrm{~Hz}$. A $\mathrm{Si}_{3} \mathrm{~N}_{4}$ cantilever tip of $0.06 \mathrm{~N} \mathrm{~m}^{-1}$ spring constant was used.

Parallel plate flow chamber and image analysis. Adhesion experiments were carried out in a parallel plate flow chamber containing three basic modules: a flow loop, a syringe pump and image analysis components (Gómez-Suárez et al., 1999). The chamber is made of poly(methyl methacrylate) with channel dimensions $76 \times 38 \times 0.6 \mathrm{~mm}(l \times w \times h)$ for deposition assays. For detachment and redeposition experiments the channel of the flow chamber was modified $(76 \times 5 \times 0.6$ $\mathrm{mm}, l \times w \times h)$ to control the passage and velocity of the air bubbles introduced. The top plate was made out of glass and separated from the bottom plate by two Teflon spacers. The bottom plate was made of glass or DDS-coated glass, depending of the substratum under study. A pulse-free liquid flow was achieved by hydrostatic pressure and recirculated by a roller pump. The volumetric flow was $0.025 \mathrm{ml} \mathrm{s}^{-1}$, yielding to a laminar flow (Reynolds number $0 \cdot 6$ ).

The entire flow chamber was mounted on the stage of a phasecontrast microscope (Olympus $\mathrm{BH}-2$ ) equipped with a $\times 40$ ultra-long working distance objective (Olympus ULWD-CD Plan 40 PL). A charged-coupled device camera (CCD-MXR/ 5010, Adimec Advanced Image Systems) was mounted on the phase-contrast microscope and connected to a PCVision ${ }^{+}$ video frame grabber interface card (Imaging Technology Inc.) to digitize the video signal. For enumeration of the number of bacteria adhering to the bottom plate before and after the passage of an air bubble, a cell-finder slide $(76 \times 26 \mathrm{~mm})$ attached to the outside of the bottom plate was focused for accurate repositioning $( \pm 2 \mu \mathrm{m})$ of the flow chamber in the enumeration process.

Experimental protocol. All experiments were performed at room temperature in triplicate with suspensions of separate bacterial cultures and newly prepared collector surfaces. Before each experiment, all tubes, flow chamber and syringe pump were filled with PBS and care was taken to remove all air bubbles from the system. The PBS solution was first perfused through the chamber for $30 \mathrm{~min}$. At this stage and when appropriate, the flow was switched to PBS supplemented with isolated EPS for $1 \mathrm{~h}$ after which the flow was switched for $30 \mathrm{~min}$ to PBS to remove all remnants of EPS components from the tubing and the flow chamber.

In deposition experiments, after perfusion with PBS, bacteria were allowed to adhere on the different substrata up to $5 \mathrm{~h}$ from a suspension containing $3 \times 10^{8}$ bacteria $\mathrm{ml}^{-1}$ in PBS supplemented with $5 \%(\mathrm{v} / \mathrm{v}) \mathrm{NB}$. Initial deposition rates and numbers of adhering cells after $5 \mathrm{~h}$ of both $P$. aeruginosa strains on bare, EPS pre-coated and DDS-coated glass were determined.

In detachment experiments, $4 \times 10^{6}$ bacteria $\mathrm{cm}^{-2}$ were allowed to adhere to the substrata from PBS supplemented with $5 \%(\mathrm{v} / \mathrm{v}) \mathrm{NB}$, as enumerated by the image analysis system on ten arbitrarily chosen areas of $0.017 \mathrm{~mm}^{2}$ distributed over the length of the substratum surface. Subsequently, flow was switched for $30 \mathrm{~min}$ to PBS, again to remove all non-adhering bacteria from the flow chamber and the tubing system. At this stage, a $0 \cdot 1 \pm 0 \cdot 02 \mathrm{ml}$ air bubble fully spanning the width of the flow chamber was introduced in the tubing and passed over the substratum surface at a controlled velocity of $5.6 \mathrm{~mm} \mathrm{~s}^{-1}$ with the aid of a syringe pump (Terumo SC512). The syringe pump was connected to the flow chamber by a three-way valve and filled with PBS. The number of bacteria that remained adhering after air bubble passage was enumerated after retrieving the positions used before with the aid of the cellfinder.

In redeposition experiments, $P$. aeruginosa was allowed to adhere to glass from a suspension with $1 \times 10^{9}$ cells ml $^{-1}$ in PBS supplemented with $5 \%(\mathrm{v} / \mathrm{v}) \mathrm{NB}$ medium up to $40 \mathrm{~min}$. Thereafter, six air bubbles were allowed to pass over the substratum surface at $5.6 \mathrm{~mm} \mathrm{~s}^{-1}$, removing all adhering bacteria. Finally, a fresh bacterial suspension was allowed to adhere again to this substratum surface and the number of adhering bacteria enumerated. This process of detachment, deposition and adhesion was repeated for up to six cycles.

The initial increase in the number of adhering bacteria with time was expressed as an initial deposition rate $\left(j_{0}\right)$. This rate was calculated in deposition and redeposition experiments and represents the number of initially adhered bacterial cells 
per unit area and time. The number of bacterial cells detached after a passing an air bubble was expressed as the percentage of bacteria caused to detach, relative to the number of adhering bacteria prior to air bubble passage.

Data analysis. Detachment data were analysed by a one-way analysis of variance (ANOVA). ANOVA tests the ratio of the mean squares between groups and within groups, and provides an $F$-ratio (i.e. Fisher distribution) and its corresponding $P$ value. If the null hypothesis is true, the $F$ ratio should be approximately 1 , since both mean squares between and within groups should be about the same. If the ratio is much larger than one, the null hypothesis is false. The shape of the $F$ distribution depends on the degrees of freedom within and between groups: the lower the degrees of freedom, the larger the value of $F$ needed for significance. A $P$ value of less than $5 \%$ was considered to indicate a significant difference between groups. The subscript of $F$ indicates the value of $F$ needed for a hypothesis to be significant at the $5 \%$ level. When differences among means were determined, post-hoc Dunnett's range tests and pairwise multiple comparisons were employed.

\section{RESULTS}

Table 1 shows the physico-chemical properties of the cell surfaces of $P$. aeruginosa SG81 and SG81R1, as well as those of the pristine, EPS-coated and DDS-coated glass. EPS-producing $P$. aeruginosa SG81 was significantly more hydrophobic $\left(F_{7 \cdot 71}=13.5, P=0.020\right)$ than strain SG81R1, as judged from water contact angles. However, no significant differences in zeta potentials $\left(F_{7.71}=3.58, P=0.131\right)$ were found in PBS. Correspondingly, there were no significant differences in elemental surface compositions of both bacterial strains. DDS-coated glass was significantly more hydrophobic than glass $\left(F_{7 \cdot 71}=346 \cdot 2, P=0 \cdot 00005\right)$, while EPS coating made glass more hydrophobic as compared to bare glass $\left(F_{7 \cdot 71}=13 \cdot 6, P=0 \cdot 021\right)$, but did not significantly affect the hydrophobicity of DDS-coated glass. No significant differences were found in zeta potentials of both substrata, as measured in PBS. Both $\mathrm{O} / \mathrm{C}$ and $\mathrm{N} / \mathrm{C}$

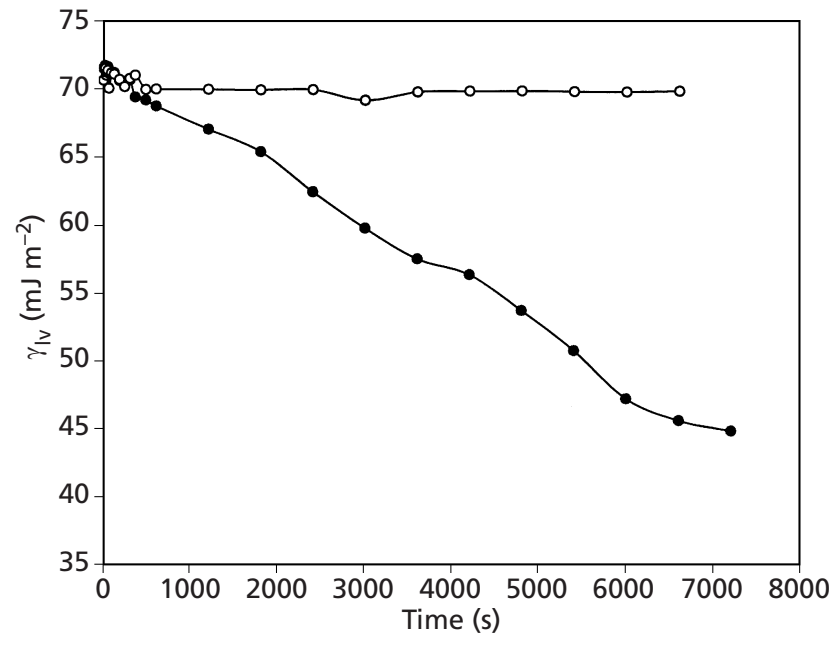

Fig. 1. Liquid surface tension $\left(\gamma_{\mathrm{lv}}\right)$ of a suspension of $P$. aeruginosa SG81 $(O)$ and $P$. aeruginosa SG81R1 $(O)\left(1 \times 10^{9}\right.$ cells $\mathrm{ml}^{-1}$ in PBS, $\mathrm{pH}$ 7.0) as a function of time as determined by ADSA-P. Data are the means of three experiments performed with separately grown bacterial strains.

elemental surface concentration ratios of glass increased significantly after EPS-coating $\left(F_{18 \cdot 51}=106 \cdot 2, P=0 \cdot 017\right)$, but an EPS coating did not significantly affect the elemental surface composition of DDS-coated glass.

A suspension of $P$. aeruginosa SG81 showed a strong decrease in liquid surface tension $\left(\gamma_{1 \mathrm{v}}\right)$ over time from 70 to $45 \mathrm{~mJ} \mathrm{~m}^{-2}$ (Fig. 1), indicating the release of surfaceactive EPS. $P$. aeruginosa SG81R1 in suspension, however, did not cause a significant change in surface tension over time. EPS-producing $P$. aeruginosa SG81 adhered significantly less well $\left(F_{4: 3}=29 \cdot 93, P=0 \cdot 00001\right)$ than the non-EPS-producing strain SG81R1, as based both on initial deposition rates and numbers of bacteria

Table 1. Water contact angles $\left(\theta_{\mathrm{w}}\right)$ on the different bacterial strains and substratum surfaces involved in this study, together with their zeta potentials $(\xi)$ in phosphatebuffered solution ( $\mathrm{pH} 7 \cdot 0$ ), and elemental surface concentration ratios from XPS

All data are the results of three experiments with separately grown bacterial strains and substratum surfaces, yielding a mean SD of around $5^{\circ}$ for contact angles, $3 \mathrm{mV}$ for zeta potentials and $0 \cdot 010$ for XPS elemental concentrations. ND, Not determined; BDL, below detection limit.

\begin{tabular}{|c|c|c|c|c|c|c|}
\hline Strain/substratum & & $\theta_{w}\left({ }^{\circ}\right)$ & $\xi(\mathrm{mV})$ & $\mathrm{N} / \mathrm{C}$ & $\mathrm{O} / \mathrm{C}$ & $\mathrm{P} / \mathrm{C}$ \\
\hline \multicolumn{7}{|l|}{ Bacterial strains } \\
\hline P. aeruginosa SG81 & & 62 & -9 & $0 \cdot 083$ & $0 \cdot 445$ & $0 \cdot 026$ \\
\hline P. aeruginosa SG81R1 & & 47 & -16 & $0 \cdot 101$ & $0 \cdot 413$ & $0 \cdot 017$ \\
\hline \multicolumn{7}{|l|}{ Substrata } \\
\hline \multirow[t]{2}{*}{ Bare } & Glass & 27 & -22 & $0 \cdot 018$ & $0 \cdot 422$ & $\mathrm{BDL}$ \\
\hline & DDS-coated glass & 99 & -20 & $0 \cdot 010$ & $1 \cdot 234$ & BDL \\
\hline \multirow[t]{2}{*}{ EPS-coated } & Glass & 41 & $\mathrm{ND}$ & $0 \cdot 086$ & $2 \cdot 303$ & $\mathrm{BDL}$ \\
\hline & DDS-coated glass & 95 & ND & $0 \cdot 031$ & $1 \cdot 521$ & BDL \\
\hline
\end{tabular}


Table 2. Initial deposition rates $\left(j_{0}\right)$, numbers of adhering organisms after $5 \mathrm{~h}$ of deposition $\left(n_{5 \mathrm{~h}}\right)$ and percentages of adhering organisms detached by a passing air bubble

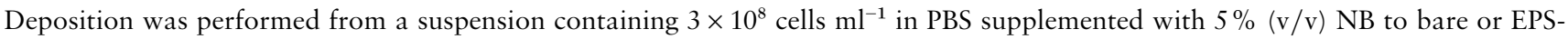
coated substrata. All data are the results of three experiments with separately grown bacterial strains and substratum surfaces, yielding a mean SD of around $11 \%$ in all parameters. ND, Not determined.

\begin{tabular}{|c|c|c|c|c|c|c|c|}
\hline \multirow[t]{2}{*}{ Substratum surface } & \multirow{2}{*}{$\begin{array}{c}\text { P. aeruginosa } \\
\text { strain }\end{array}$} & \multicolumn{2}{|c|}{$j_{0}\left(\mathrm{~cm}^{-2} \mathrm{~s}^{-1}\right)$} & \multicolumn{2}{|c|}{$10^{-6} \times n_{5 \mathrm{~h}}\left(\mathrm{~cm}^{-2}\right)$} & \multicolumn{2}{|c|}{ Detachment $(\%)$} \\
\hline & & Bare & EPS-coated & Bare & EPS-coated & Bare & EPS-coated \\
\hline \multirow[t]{2}{*}{ Glass } & SG81 & 2250 & 1547 & $15 \cdot 3$ & $7 \cdot 8$ & 38 & ND \\
\hline & SG81R1 & 5450 & 2800 & $22 \cdot 5$ & $8 \cdot 5$ & 28 & $\mathrm{ND}$ \\
\hline \multirow[t]{2}{*}{ DDS-coated glass } & SG81 & 2000 & 1263 & $11 \cdot 5$ & $6 \cdot 1$ & 15 & ND \\
\hline & SG81R1 & 5100 & 2550 & $12 \cdot 8$ & $9 \cdot 4$ & 9 & ND \\
\hline
\end{tabular}

adhering after $5 \mathrm{~h}$ (Table 2). However, both strains adhered faster (higher deposition rates) and in higher numbers to hydrophilic glass than to hydrophobic DDScoated glass. Coating of the substrata with isolated EPS prior to bacterial deposition yielded a significant decrease in initial deposition rates $\left(F_{4 \cdot 3}=10 \cdot 34, P=0.004\right)$ and numbers of bacteria adhering after $5 \mathrm{~h}\left(F_{4 \cdot 3}=25 \cdot 73\right.$, $P=0.00004)$ as compared to pristine substrata for both strains. However, these decreases were less important for the EPS-producing strain. No significant differences were found in the detachment of the strains, as induced by the passage of an air bubble through the flow chamber, but their detachment from hydrophilic glass was significantly higher $\left(F_{7 \cdot 71}=172 \cdot 1, P=0 \cdot 0002\right)$ than from hydrophobic DDS-coated glass.

Fig. 2 shows that the initial deposition rate and the number of adhering $P$. aeruginosa SG81 R1 after $40 \mathrm{~min}$ $\left(n_{40 \mathrm{~min}}\right)$ to glass decrease linearly with the number of detachment and deposition cycles, becoming similar to the results obtained for EPS-producing SG81 after six cycles.

The surface chemical compositions of gold-coated glass after air-bubble-induced detachment of adhering $P$. aeruginosa SG81 and SG81 R1 of the first two cycles of detachment and deposition were determined by XPS, as presented in Table 3 . The $\mathrm{C}_{1 \mathrm{~s}}$ carbon peak was decomposed in four components and attributed to: carbon bound only to carbon and hydrogen, $\underline{\mathrm{C}}-(\mathrm{C}, \mathrm{H})$, at a binding energy of $284.8 \mathrm{eV}$; carbon singly bound to oxygen or nitrogen, $\mathrm{C}-(\mathrm{O}, \mathrm{N})$, including ether, alcohol, amine and amide bonds, at a binding energy of $286 \cdot 2 \mathrm{eV}$; carbon with either two single bonds to oxygen or one double bond, $\underline{C}=\mathrm{O}$, including amide, carbonyl, carboxylate, ester, acetal and hemiacetal bonds, at a binding energy of $287 \cdot 8 \mathrm{eV}$; and finally, carbon involved in carboxyl groups, $\mathrm{O}=\mathrm{C}-\mathrm{OH}$, at $289 \cdot 1 \mathrm{eV}$. The EPS of agar-grown $P$. aeruginosa SG81 has been described (Grobe et al., 1995) to contain uronic acids (UA), proteins (PR) and polysaccharides (PS). Based on these compositional data, the XPS results in Table 3 enable determination of the composition of the EPS left on the gold after detachment, as described by Rouxhet et al.
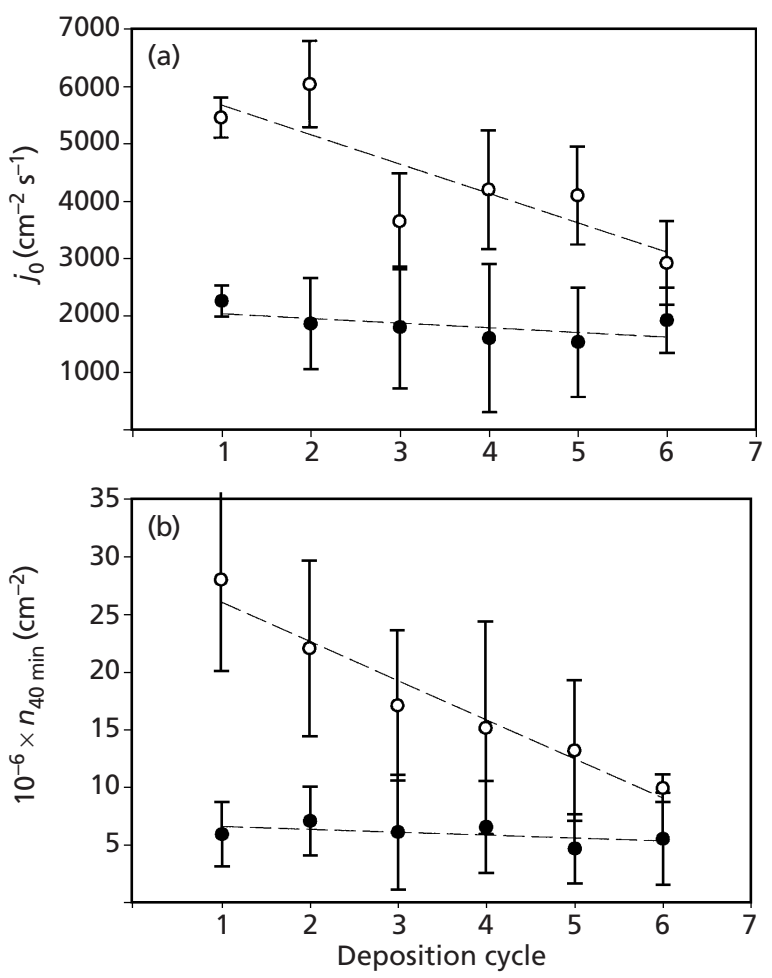

Fig. 2. Adhesion of $P$. aeruginosa SG81 (O) and $P$. aeruginosa SG81R1 (O) from a $5 \%(\mathrm{v} / \mathrm{v})$ NB medium supplemented with PBS $(\mathrm{pH} 7.0)$ to glass as a function of the number of detachment and deposition cycles. (a) Initial deposition rates $\left(j_{0}\right)$; (b) number of adhering of $P$. aeruginosa after $40 \mathrm{~min}$ $\left(n_{40 \mathrm{~min}}\right)$. Bars indicate the standard deviation of three experiments performed with separately grown bacterial strains and substratum surfaces.

(1994). Accordingly, the $\mathrm{O}=\underline{\mathrm{C}}-\mathrm{OH}$ peak was attributed to uronic acids yielding:

$(\mathrm{O}=\underline{\mathrm{C}}-\mathrm{OH}) / \mathrm{C}=\mathrm{C}_{\mathrm{UA}}$

in which $\mathrm{C}_{\mathrm{UA}}$ denotes the ratio of carbon due to uronic acids. Similarly, the ratio of carbon due to proteins, $\mathrm{C}_{\mathrm{PR}}$, was obtained from the $\mathrm{N} / \mathrm{C}$ ratio, assuming 
Table 3. Chemical composition of gold-coated glass after air-bubble-induced detachment of adhering bacteria after the first two cycles of detachment and deposition, as determined by XPS, and calculated contents of uronic acids $\left(C_{U A}\right)$, proteins $\left(\mathrm{C}_{\mathrm{PR}}\right)$, polysaccharides $\left(\mathrm{C}_{\mathrm{PS}}\right)$ and hydrocarbon-like compounds $\left(\mathrm{C}_{\mathrm{HC}}\right)$, according to equations $1-4$

\begin{tabular}{|lccccccccc|}
\hline Strain & $\begin{array}{c}\text { Redeposition } \\
\text { cycle }\end{array}$ & $\mathrm{N} / \mathrm{C}$ & $\mathrm{O} / \mathrm{C}$ & $(\mathrm{O}=\underline{\mathrm{C}}-\mathrm{OH}) / \mathrm{C}$ & {$[\mathrm{C}-(\mathrm{O}, \mathrm{N})] / \mathrm{C}$} & $\mathrm{C}_{\mathrm{UA}}$ & $\mathrm{C}_{\mathrm{PR}}$ & $\mathrm{C}_{\mathrm{PS}}$ & $\mathrm{C}_{\mathrm{HC}}$ \\
\hline P. aeruginosa SG81 & 1 & $0 \cdot 177$ & $0 \cdot 312$ & $0 \cdot 032$ & $0 \cdot 496$ & $0 \cdot 032$ & $0 \cdot 634$ & $0 \cdot 287$ & $0 \cdot 047$ \\
& 2 & $0 \cdot 150$ & $0 \cdot 275$ & $0 \cdot 072$ & $0 \cdot 457$ & $0 \cdot 072$ & $0 \cdot 538$ & $0 \cdot 235$ & $0 \cdot 155$ \\
P. aeruginosa SG81R1 & 1 & $0 \cdot 189$ & $0 \cdot 329$ & $0 \cdot 027$ & $0 \cdot 500$ & $0 \cdot 027$ & $0 \cdot 677$ & $0 \cdot 284$ & $0 \cdot 012$ \\
& 2 & $0 \cdot 171$ & $0 \cdot 320$ & $0 \cdot 043$ & $0 \cdot 472$ & $0 \cdot 043$ & $0 \cdot 613$ & $0 \cdot 258$ & $0 \cdot 086$ \\
\hline
\end{tabular}
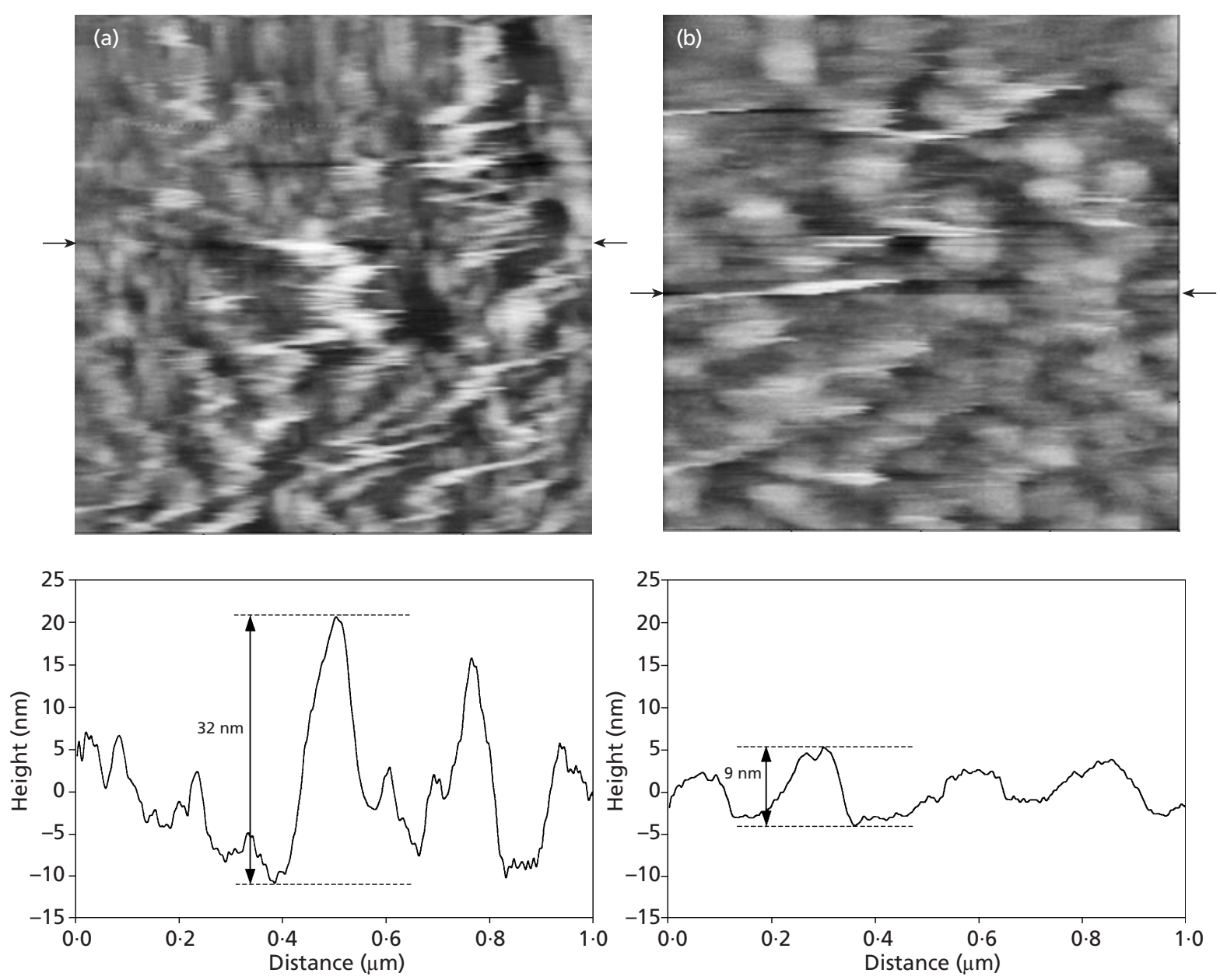

Fig. 3. Height AFM images recorded under water (area: $1 \mu \mathrm{m} \times 1 \mu \mathrm{m}$ ) of glass after one cycle of air-bubble-induced detachment of adhering $P$. aeruginosa. (a) $P$. aeruginosa SG81; (b) $P$. aeruginosa SG81R1. The arrows indicate the lines along which cross sections, shown in the respective graphs below, were taken.

proteins possess about $0 \cdot 28$ nitrogen atoms per molecule:

$\mathrm{N} / \mathrm{C}=0.28 \times \mathrm{C}_{\mathrm{PR}}$

As proteins contain negligible amounts of carbon singly bound to oxygen (Dûfrene \& Rouxhet, 1996), the ratio of carbon due to polysaccharides, $\mathrm{C}_{\mathrm{PS}}$, can be calculated from:

$[\underline{\mathrm{C}}-(\mathrm{O}, \mathrm{N})]-\mathrm{N} / \mathrm{C}-\mathrm{C}_{\mathrm{UA}}=\mathrm{C}_{\mathrm{PS}}$
A residual content due to hydrocarbon-like compounds, $\mathrm{C}_{\mathrm{HC}}$, subsequently results according to:

$1=\mathrm{C}_{\mathrm{UA}}+\mathrm{C}_{\mathrm{PR}}+\mathrm{C}_{\mathrm{PS}}+\mathrm{C}_{\mathrm{HC}}$

Based on this analysis, it can be concluded (see also Table 3) that the EPS left after detachment contains up to $68 \%$ protein. The amounts of protein $\left(\mathrm{C}_{\mathrm{PR}}\right)$ and polysaccharides $\left(\mathrm{C}_{\mathrm{PS}}\right)$ decreased significantly $\left(F_{7 \cdot 71}=\right.$ $158 \cdot 4, P=0 \cdot 002)$ after the second deposition cycle for 
Table 4. Mean roughness $\left(R_{\mathrm{a}}\right)$ of glass prior to and after two cycles of detachment and deposition of $P$. aeruginosa SG81 and SG81R1, as calculated from AFM height images

All data are means \pm SD based on measurements on three different areas of two experiments with separately grown bacterial strains and substratum surfaces.

\begin{tabular}{|llr|}
\hline Substratum & $\begin{array}{c}\boldsymbol{P} \text {. aeruginosa } \\
\text { strain }\end{array}$ & $\boldsymbol{R}_{\mathrm{a}}(\mathbf{n m})$ \\
\hline Bare glass & & $1 \cdot 0 \pm 0 \cdot 1$ \\
After redeposition cycle 1 & SG81 & $4 \cdot 6 \pm 4 \cdot 0$ \\
& SG81R1 & $1 \cdot 4 \pm 0 \cdot 2$ \\
After redeposition cycle 2 & SG81 & $13 \cdot 5 \pm 9 \cdot 4$ \\
& SG81R1 & $2 \cdot 5 \pm 0 \cdot 8$ \\
\hline
\end{tabular}

both strains, leaving significantly higher $\left(F_{7 \cdot 71}=162 \cdot 4\right.$, $P=0.02$ ) amounts of uronic acids. However, the increase in $\mathrm{C}_{\mathrm{UA}}$ was significantly higher for the EPS-producing strain SG81 than for the non-EPS-producing strain SG81R1.

Topographic height AFM images of EPS left on glass after the first air-bubble-induced detachment of adhering P. aeruginosa are shown in Fig. 3. Streaks oriented in the direction of the scan can be observed for both SG81 and SG81R1. However, those from the EPSproducing strain were more numerous. A cross-section of those streaks revealed an irregular film of thickness ranging from 3 to $32 \mathrm{~nm}$ for the EPS-producing SG81, and from 1.5 to $9 \mathrm{~nm}$ for the non-EPS-producing strain SG81R1. The mean surface roughness, $R_{\mathrm{a}}$, of the substrata after the first deposition cycle of the EPSproducing strain increased significantly $\left(F_{7 \cdot 71}=10 \cdot 36\right.$, $P=0.032$ ), as compared to bare glass substratum (Table 4). No significant difference was found between the roughness of glass prior to and after adhesion and detachment of the non-EPS-producing strain SG81R1, but after the second cycle of deposition and detachment, a significantly elevated $\left(F_{7 \cdot 71}=10 \cdot 3, P=0.008\right)$ mean roughness was observed for both strains.

\section{DISCUSSION}

In this study, the role of EPS in the initial adhesion of an EPS-producing and an EPS-non-producing P. aeruginosa strain to inert substrata with different hydrophobicity was investigated. Both strains adhered better to a hydrophilic than to a hydrophobic substratum, while bacterial EPS production, as well as pre-coating a substratum surface with isolated EPS, discouraged bacterial adhesion. Moreover, an anchoring effect of EPS production could not be observed because, despite its EPS production, a slightly higher percentage of strain SG81 cells were detached by a passing air bubble than the non-producing strain SG81R1. Detachment percentages were, however, low for both strains (Gómez-
Suárez et al., 2001) and the strains left EPS behind as footprints on the substratum surface. The height of protuberances in the EPS left behind are consistent with the sizes of globular proteins, such as lysozyme $(4.5 \times 3.0 \times 3.0 \mathrm{~nm})$ and albumin $(11.6 \times 2.7 \times 2.7 \mathrm{~nm})$ (Haynes \& Norde, 1994).

Most often and contrary to the present findings, EPS is reported to enhance bacterial adhesion to inert substrata (Costerton et al., 1985; Van Loosdrecht et al., 1990). For instance, Dûfrene et al. (1996a) found that adhesion of Azospirillum brasilense to both hydrophilic and hydrophobic substrata occurred only after stimulated EPS production and correlated it to an increase of protein content of the EPS over time. A similar increase in adhesion of Pseudomonas fluorescens associated with high protein contents in EPS has been reported by DeFlaun et al. (1990). Recently, Azeredo \& Oliveira (2000) found that the presence of surface-active compounds increased the adhesion of Sphingomonas paucimobilis to glass.

It is interesting that the non-EPS-producing strain, as shown in this study by a lack of a decrease in surface tension of a suspension of strain SG81R1, has cell surface characteristics similar to those of the EPSproducer SG81. Moreover, after repeated cycles of deposition and detachment, SG81R1 shows similar adhesion behaviour to SG81, and also the substratum characteristics after detachment become alike. This indicates that SG81R1 excretes minor amounts of EPS, undetectable by ADSA-P. The role of this EPS in discouraging bacterial adhesion only becomes evident after several cycles of detachment and deposition. Recently, production of a minor amount of EPS by $P$. aeruginosa SG81R1, growing in a biofilm, has been described by Strathmann et al. (2002). Alternatively, Vandevivere \& Kirchman (1993) as well as Allison \& Sutherland (1987) suggested that attachment stimulates bacterial EPS synthesis, and putatively non-EPSproducing $P$. aeruginosa strains related to cystic fibrosis could through mutation or selection turn into EPSproducing ones during adaptation to different ecological sites, such as stress and growth conditions (Boucher et al., 2000; Grobe et al., 1995).

The EPS excreted by $P$. aeruginosa SG81 is highly surface active, which is probably due to a uronic-acidcontaining polymer. Grobe et al. (1995) have analysed the chemical composition of EPS excreted by $P$. aeruginosa SG81 grown on Pseudomonas Isolation Agar and found that the crude extracellular material of this strain contained polysaccharides $(16.4 \%)$, uronic acids $(79.3 \%)$ and small amounts of proteins $(4.3 \%)$. The chemical composition obtained by XPS of the footprints left behind by $P$. aeruginosa after air-bubble-induced detachment showed a greater content of uronic acid in the footprints of the EPS-producing strain than of the putatively non-EPS-producing strain. The uronic acid content calculated increased with the number of detachment and redeposition cycles. Uronic acids (i.e. mannuronic and glucuronic acids) excreted by P. fluor- 
escens strains have been reported to have surface-active properties, preventing their adhesion to surfaces (Pringle et al., 1983), an effect similar to that of the uronic acids excreted by the $P$. aeruginosa strain in this study. These findings agree with earlier studies that showed how the excretion of surface-active material by lactobacilli (McGroarty \& Reid, 1988; Velraeds et al., 1998a), Streptococcus thermophilus (Busscher et al., 1997) or Streptococcus mutans (Van Hoogmoed et al., 2000) either discourage their own adhesion or adhesion of competitors to substrata.

\section{REFERENCES}

Allison, D. G. \& Sutherland, I. W. (1987). The role of exopolysaccharides in adhesion of freshwater bacteria. J Gen Microbiol 133, 1319-1327.

Azeredo, J. \& Oliveira, R. (2000). The role of exopolymer in the attachment of Sphingomonas paucimobilis. Biofouling 16, 59-67.

Azeredo, J., Visser, J. \& Oliveira, R. (1999). Exopolymer in bacterial adhesion: interpretation in terms of DLVO and xDVLO theories. Colloids Surf B: Biointerfaces 14, 141-148.

Beech, I., Hanjagsit, L., Kalaji, M., Neal, A. L. \& Zinkevich, V. (1999). Chemical and structural characterization of exopolymer produced by Pseudomonas sp. NCIMB 2021 in continuous culture. Microbiology 145, 1491-1497.

Bos, R., Van der Mei, H. C. \& Busscher, H. J. (1995). A quantitative method to study co-adhesion of micro-organisms in a parallel plate flow chamber. II: Analysis of the kinetics of co-adhesion. $J$ Microbiol Methods 23, 169-182.

Boucher, J. C., Schurr, M. J. \& Deretic, V. (2000). Dual regulation of mucoidity in Pseudomonas aeruginosa and sigma factor antagonism. Mol Microbiol 36, 341-351.

Busscher, H. J., Weerkamp, A. H., Van der Mei, H. C., Van Pelt, A. W. J., De Jong, H. P. \& Arends, J. (1984). Measurements of the surface free energy of bacterial cell surfaces and its relevance for adhesion. Appl Environ Microbiol 48, 980-983.

Busscher, H. J., Cowan, M. M. \& Van der Mei, H. C. (1992). On the relative importance of specific and non-specific approaches to oral microbial adhesion. FEMS Microbiol Lett 88, 199-210.

Busscher, H. J., Bos, R. \& Van der Mei, H. C. (1995). Initial microbial adhesion is a determinant for the strength of biofilm adhesion. FEMS Microbiol Lett 128, 229-234.

Busscher, H. J., Van Hoogmoed, C. G., Geertsema-Doornbusch, G. I., Van der Kuijl-Booij, M. \& Van der Mei, H. C. (1997). Streptococcus thermophilus and its biosurfactants inhibit adhesion by Candida spp. on silicone rubber. Appl Environ Microbiol 63, 3810-3817.

Cheng, P., Li, D., Boruvka, L., Rotenberg, Y. \& Neumann, A. W. (1990). Automation of axisymmetric drop shape analysis for measurements of interfacial tensions and contact angles. Colloids Surf 43, 151-167.

Christensen, B. E. \& Characklis, W. G. (1990). Physical properties of biofilms. In Biofilms, pp. 93-130. Edited by W. G. Characklis \& K. C. Marshall. New York: Wiley.

Cooksey, K. E. (1992). Extracellular polymers in biofilms. In Biofilms: Science and Technology, pp. 137-147. Edited by L. F. Melo, M. Fletcher \& T. R. Bott. Dordrecht: Kluwer.

Cooksey, K. E. \& Wigglesworth-Cooksey, B. (1995). Adhesion of bacteria and diatoms to surfaces in the sea: a review. Aquat Microbiol Ecol 9, 87-96.

Costerton, J. W., Marrie, C. B. \& Cheng, K.-J. (1985). Phenomena of bacterial adhesion. In Bacterial Adhesion, pp. 3-43. Edited by D. C. Savage \& M. Fletcher. New York: Plenum.

Danielsson, A., Norkrans, B. \& Bjornsson, A. (1977). On bacterial adhesion - the effect of certain enzymes on adhered cells of a marine Pseudomonas sp. Bot Mar 20, 13-17.

Deflaun, M. F., Tanzer, A. S., McAteer, A. L., Marshall, B. \& Levy, S. B. (1990). Development of an adhesion assay and characterization of an adhesion-deficient mutant of Pseudomonas fluorescens. Appl Environ Microbiol 56, 112-119.

Dûfrene, Y. F. \& Rouxhet, P. G. (1996). X-ray photoelectron spectroscopy analysis of the surface composition of Azospirillum brasilense in relation with growth conditions. Colloids Surf B: Biointerfaces 7, 271-279.

Dûfrene, Y. F., Boonaert, J.-P. \& Rouxhet, P. G. (1996a). Adhesion of Azospirillum brasilense: role of the proteins at the cell-support interface. Colloids Surf B: Biointerfaces 7, 113-128.

Dûfrene, Y. F., Vermeiren, H., Vanderleyden, J. \& Rouxhet, P. G. (1996b). Direct evidence for the involvement of extracellular proteins in the adhesion of Azospirillum brasilense. Microbiology 142, 855-865.

Escher, A. \& Characklis, W. G. (1990). Modeling the initial events in biofilm accumulation. In Biofilms, pp. 445-486. Edited by W. G. Characklis \& K. C. Marshall. New York: Wiley.

Flemming, H.-C. \& Wingender, J. (2001). Relevance of microbial polymeric substances (EPSs) - part I: structural and ecological aspects. Water Sci Technol 43, 1-8.

Fletcher, M. \& Floodgate, G. D. (1973). An electron-microscopic demonstration of an acidic polysaccharide involved in the adhesion of a marine bacterium to solid surface. J Gen Microbiol 74, 325-334.

Gómez-Suárez, C., Noordmans, J., Van der Mei, H. C. \& Busscher, H. J. (1999). Removal of colloidal particles from quartz collector surfaces as stimulated by the passage of air-liquid interfaces. Langmuir 15, 5123-5127.

Gómez-Suárez, C., Busscher, H. J. \& Van der Mei, H. C. (2001). Analysis of bacterial detachment from substratum surfaces by the passage of air-liquid interfaces. Appl Environ Microbiol 67, 2531-2537.

Grobe, S., Wingender, J. \& Trüper, H. G. (1995). Characterization of mucoid Pseudomonas aeruginosa strains isolated from technical water systems. J Appl Bacteriol 79, 94-102.

Habash, M. H., Van der Mei, H. C., Reid, G. \& Busscher, H. J. (1997). Adhesion of Pseudomonas aeruginosa to silicone rubber in a parallel plate flow chamber in the absence and presence of nutrient broth. Microbiology 143, 2569-2574.

Haynes, C. A. \& Norde, W. (1994). Globular proteins at solid/ liquid interfaces. Colloids Surf B: Biointerfaces 2, 517-566.

Heinemann, C., Van Hylckama Vlieg, J. E. T., Janssen, D. B., Busscher, H. J., Van der Mei, H. C. \& Reid, G. (2000). Purification and characterization of a surface-binding protein from Lactobacillus fermentum RC-14 that inhibits adhesion of Enterococcus faecalis 1131. FEMS Microbiol Lett 190, 177-180.

Hiemenz, P. C. (1977). Electrophoresis and other electrokinetic phenomena. In Principles of Colloid and Surface Chemistry, pp. 452-487. Edited by J. J. Lagowski. New York: Marcel Dekker.

Landa, A. S., Van der Mei, H. C., Van Rij, G. \& Busscher, H. J. (1998). Efficacy of ophthalmic solutions to detach adhering Pseudomonas aeruginosa from contact lenses. Cornea 17, 293300.

McGroarty, J. A. \& Reid, G. (1988). Detection of a lactobacillus substance that inhibits Escherichia coli. Can J Microbiol 34, 974-978. 
Neu, T. R. (1992). Microbial 'footprints' and the general ability of micro-organisms to label interfaces. Can J Microbiol 38, 10051008.

Neu, T. R. \& Marshall, K. C. (1990). Bacterial polymers: physicochemical aspects of their interactions at interfaces. J Biomater Appl 5, 107-133.

Neu, T. R. \& Marshall, K. C. (1991). Microbial footprints - a new approach to adhesive polymers. Biofouling 3, 101-112.

Nielsen, P. H., Jahn, A. \& Palmgren, R. (1997). Conceptual model for production and composition of exopolymers in biofilms. Water Sci Technol 36, 11-19.

Omar, A. S., Wecksser, J. \& Mayer, H. (1983). Different polysaccharides in the external layers (capsule and slime) of the cell envelope of Rhodopseudomonas capsulata Sp11. Arch Microbiol 136, 291-296.

Pringle, J. H., Fletcher, M. \& Ellwood, D. C. (1983). Selection of attachment mutants during the continuous culture of Pseudomonas fluorescens and relationship between attachment ability and surface composition. J Gen Microbiol 129, 2557-2569.

Rouxhet, P. G., Mozes, N., Dengis, P. B., Dûfrene, Y. F., Gerin, P. A. \& Genet, M. J. (1994). Application of X-ray photoelectron spectroscopy to micro-organisms. Colloids Surf B: Biointerfaces $2,347-369$.

Schmitt, J. \& Flemming, H.-C. (1999). Water binding in biofilms. Water Sci Technol 39, 77-82.

Schmitt, J., Fringeli, U. P. \& Flemming, H.-C. (1997). Structural and temporal behavior of biofilms investigated by FTIR-ATR spectroscopy. In Proceedings of the 11th Conference on Fourier Transform Spectroscopy. American Institute of Physics Press.

Strathmann, J., Wingender, J. \& Flemming, H.-C. (2002). Application of fluorescently labelled lectins for the visualisation and biochemical characterisation of polysaccharides in biofilms of Pseudomonas aeruginosa. J Microbiol Methods (in press).

Sutherland, I. W. (1977). Bacterial exopolysaccharides, their nature and production. In Surface Carbohydrates of the Prokaryotic Cell, pp. 27-96. Edited by I. W. Sutherland. London, New York, San Francisco: Academic Press.

Sutherland, I. W. (1997). Microbial biofilm exopolysaccharides superglues or velcro? In Biofilms, Community Interactions and
Control, pp. 33-39. Edited by J. W. Wimpenny, P. Handley, P. Gilbert, H. M. Lappin-Scott \& M. Jones. Cardiff: Bioline.

Urzi, C., Lisi, S., Criseo, G. \& Pernice, A. (1991). Adhesion and degradation of marble by Micrococcus strain isolated from it. Geomicrobiol J 9, 81-90.

Vandevivere, P. \& Kirchman, D. L. (1993). Attachment stimulates exopolysaccharide synthesis by a bacterium. Appl Environ Microbiol 59, 3280-3286.

Van Hoogmoed, C. G., Van der Kuijl-Booij, M., Van der Mei, H. C. \& Busscher, H. J. (2000). Inhibition of Streptococcus mutans NS adhesion to glass with and without a salivary conditioning film by biosurfactant-realizing Streptococcus mitis strains. Appl Environ Microbiol 66, 659-663.

Van Loosdrecht, M., Norde, W., Lyklema, L. \& Zehnder, J. (1990). Hydrophobic and electrostatic parameters in bacterial adhesion. Aquat Sci 51, 103-114.

Van Oss, C. J. \& Gillman, M. K. (1972). Phagocytosis as a surface phenomenon. I. Contact angles and phagocytosis of nonopsonized bacteria. J Reticuloendothel Soc 12, 283-292.

Van Wagenen, R. J. \& Andrade, J. D. (1980). Flat plate streaming potential investigations : hydrodynamics and electrokinetic equivalency. J Colloid Interface Sci 76, 305-314.

Velraeds, M. M. C., Van de Belt-Gritter, B., Van der Mei, H. C., Reid, G. \& Busscher, H. J. (1998a). Interference in initial adhesion of uropathogenic bacteria and yeasts to silicone rubber by a Lactobacillus acidophilus biosurfactant. J Med Microbiol 47, 1081-1085.

Velraeds, M. M. C., Van der Mei, H. C., Reid, G. \& Busscher, H. J. (1998b). Physicochemical and biochemical characterization of biosurfactants released by Lactobacillus strains. Colloids Surf B : Biointerfaces 8, 51-61.

Williams, V. \& Fletcher, M. (1996). Pseudomonas fluorescens adhesion and transport through porous media are affected by lipopolysaccharides composition. Appl Environ Microbiol 62, 100-104.

Received 24 September 2001; revised 17 December 2001; accepted 21 December 2001. 